\title{
The role of Motivational Factors on Employee Engagement at Readymade Garments Industry, with Leadership as Moderator
}

\author{
Dalowar Hossan* \\ Department of Management and Marketing \\ University Putra Malaysia \\ dalowarhossan.bd@gmail.com \\ Dr. Zuraina Binti Dato' Mansor \\ Associate Professor \\ Department of Management and Marketing \\ University Putra Malaysia \\ aina_m@upm.edu.my \\ Mst Fahima Aktar \\ Department of Management and Marketing \\ University Putra Malaysia \\ fahimahaque555@gmail.com \\ Nurain binti mohd roshedi \\ Statistician \\ Beta Consultancy \\ Perdana Selatan, Selangor, Malaysia \\ betaconsultancyl@gmail.com \\ Saurov Roy \\ Director \\ Department of Management and Marketing \\ S. B. Laboratories Ltd., Bangladesh \\ S. B. Group of Health Service, Bangladesh \\ roysaurov@yahoo.com
}

\begin{abstract}
The current study aims to extend the literature by examining the moderating effect of leadership styles on the relationship between motivational factors and employee engagement in the context of the readymade garment (RMG) industry of Bangladesh where both leadership styles, motivational factors and employee engagement are known to be at an unsatisfactory level. The study used Herzberg's two-factor theory and the full range leadership model. Quantitative technique had been used and the hypotheses were investigated through path coefficient analysis of 387 employees at the RMG industry of Bangladesh. The findings show that extrinsic motivational factors, intrinsic motivational factors, transactional leadership style and transformational leadership style have significant effect on employee engagement as well as transactional leadership style moderates the relationship between intrinsic motivational factors and employee engagement. The paper discusses the implications of the findings and provides constructive suggestions on how to use motivational factors and leadership styles to positively impact employee engagement. The conclusions recommend that the industry focuses on leadership styles and motivational factors in order to fulfil more ambitious targets and sustain business for the long term.
\end{abstract}

Keywords: Employee Engagement, Motivational Factors, Leadership styles, Readymade Garments (RMG) 


\section{INTRODUCTION}

Over half a century ago it was recognized that motivational factors and motivational issues need to be optimized [1] if employee engagement is to increase. Many studies supported it such as [2] and [3] who both stated that motivation can increase employee engagement. The issue of employee engagement remains very important to policymakers and, more importantly, to employers [4]. For example, despite being the biggest earner in South Asia, the garment industry in Bangladesh recently experienced a decline in sales between 2015 and 2017 [5]. The study was suggested that this decline was due to underperforming employees who were not engaged and turnover intention was also very high [6]. An uncomfortable working environment will, of course, make any employee feel that they have no control over their work and exhausted. As previous research suggests, employees' perceptions of role overload will lead to a negative impact on their work attitude and behavior [7,8]. [9] also observed that job insecurity was the main source of stress for Chinese employees.

This study adopted Herzberg's motivation-hygiene theory as it supports the common-sense association of level of work gratification and job discontent, in spite of his theory not featuring leadership style as having a real effect on employee behavior and action or engagement. This paper aims to examine the effect of transformational leadership and transactional leadership, asking whether or not such factors strengthen an employee's satisfaction, motivation and engagement. Although many studies for example, $[10,11,12,13,14]$ have been conducted on motivational factors and employee engagement or leadership and employee engagement on the basis of cross sectional study, to the best of the author's knowledge, very few studies have been conducted on the role of transformational and transactional leadership as a mediator between motivation and employee engagement. [15] and [16] studied leadership style and employee engagement, specifically transformational leadership, finding that leadership played a significant role in enhancing employee engagement. While [16] used Social Exchange Theory (SET), for this paper Herzberg motivation theory is used.

\section{LITERATURE REVIEW}

\subsection{Employee Engagement}

Work engagement, according to [17], is defined as a positive, fulfilling, work-related state of mind that is characterized by vigor, dedication, and absorption. Employees will be perceived as engaged when they are able to perform their roles and hold trust on the part of management [18]. Engaged employees will work with passion and will be more committed to the organisation, since by being engaged an employee reaches the level where they may feel enjoyment and belief in what they do and feel valued by their employer [19].

Employee engagement constructs can be measured using the Utrecht Work Engagement Scale [20] which was developed to measure the dimensions vigour, dedication, and absorption. UWES has been validated across many cultures and past researchers (e.g., [21]) have acknowledged that it can be used without bias because the three-factor model has been proven with cross-national validity.

\subsection{Motivational Factors and Employee Engagement}

The literature suggests that engagement is a motivational construct and can be shared by employees in the workplace. For example, [22] found that employee engagement is fundamentally a motivational concept that represents the active allocation of personal resources towards the task associated with a work role.

Past research has examined various factors which might influence employee engagement based on certain theories. For example, [16] used SET to test antecedents such as reward and recognition, leadership, career development opportunities and subordinate and supervisor relationships. [23] used McFarlan's model to examine the impact of a variety of antecedents, such as 'the work sanctuary', wages, employed situations, connections through bosses, connections with co-workers, prizes and 
acknowledgment, offers and prospects to usage thoughts, types of toil idea of self, communication and connection with organisation, well-being dealings, healthiness settings, training, personal alteration, security, communal and civic life, opportunity for advancement, job clarity, cleanliness, stress relaxation and chances to learn a job.

In the literature, motivation is always seen as one of the most important factors for attracting and retaining employees, as well as for leading workers to be innovative and inventive [24]. [25] stated that even though a large quantity of theories have been proposed to clarify the various distinct stimuli to perform work-related tasks, little is known about the underlying factors influencing motivation and employee engagement.

RMG factories in Bangladesh have common issues related to the wellbeing of workers, the labour setting, training and career progress, compensation and working policies which are all elements of motivation affecting employee engagement. Based on these situations, this study proposed examing motivational factors using the Herzberg two-factor theory, as this theory is able to describe how levels of satisfaction and dissatisfaction are important prior to employees gaining motivation. This theory also suggests that employees will not be satisfied if intrinsic factors are not available in the workplace [26]. On the other hand, extrinsic motivational factors such as hygiene, relationship with supervisor and company policy may also determine the satisfaction of the employee and, conversely, dissatisfaction if these factors are lacking [27].

\subsection{Leadership Styles Moderate the Relationship between Motivational Factors and Employee Engagement}

Previous research suggests that there is a dyadic relationship between employees and supervisors (Dai et al., 2018) and that both transformational and transactional factors are found to have a significant relationship with motivation and employee engagement. As suggested by [28] intrinsic motivation and its components have a positive and significant association with transformational leadership and furthermore, according to the full-range leadership theory of [29], transformational leaders motivate their employees intrinsically and these kinds of elements drives from motivator factors of Herzberg. On the other hand, [30] specified that transactional leaders use a method of reward and punishment for employees: when a leader has high instrumental motivation, he/she will be more likely to have a higher level of transactional behavior. However, according to full-range leadership theory, transactional leaders motivate their employees extrinsically and these kinds of elements are derived from the hygienic factors of Herzberg.

Although past studies examined a variety of factors that can affect the development of employee engagement, extended research is still required to cover leadership and behavior, [31]. According to [32], the influence of leadership behavior and the development of employee engagement is still limited but past research has stated that leaders are able effect real change using the interactive process between them and their followers (Rowe and Guerrero, 2011). In their full range leadership model, [29] discussed eight behavioral magnitudes of transformational and transactional leadership style. While transformational leaders are able to transform and change current practices and structures by influencing others, especially with new ideas and opportunities, transactional leaders are leaders who work for the sustainability and stability of an existing system, realizing the necessity of economic and social changes for specific purposes [33].

As this study is related to leadership, the full range leadership model is adopted, since both transformational and transactional leadership style have affected workers' performance as well their engagement; factors which ultimately determine the relationship between the managers/supervisors and the workers. [34] highlighted that leadership styles which are practiced in any organization have an impact on the overall performance of those organizations. [14] added that leadership style contributes to ensuring high levels of engagement among employees.

\section{OBJECTIVE}

The objective of this study is

(1) To examine the relationship between motivational factors and employee engagement as well as leadership styles and employee engagement at the readymade garments industry in Bangladesh.

(2) To examine the moderating role of leadership styles between the relationship of motivational factors and employee engagement at the readymade garments industry in Bangladesh. 


\section{HYPOTHESIS DEVELOPMENT}

Based on an overview of previous studies, as presented in this literature review, this paper has developed the following hypotheses:

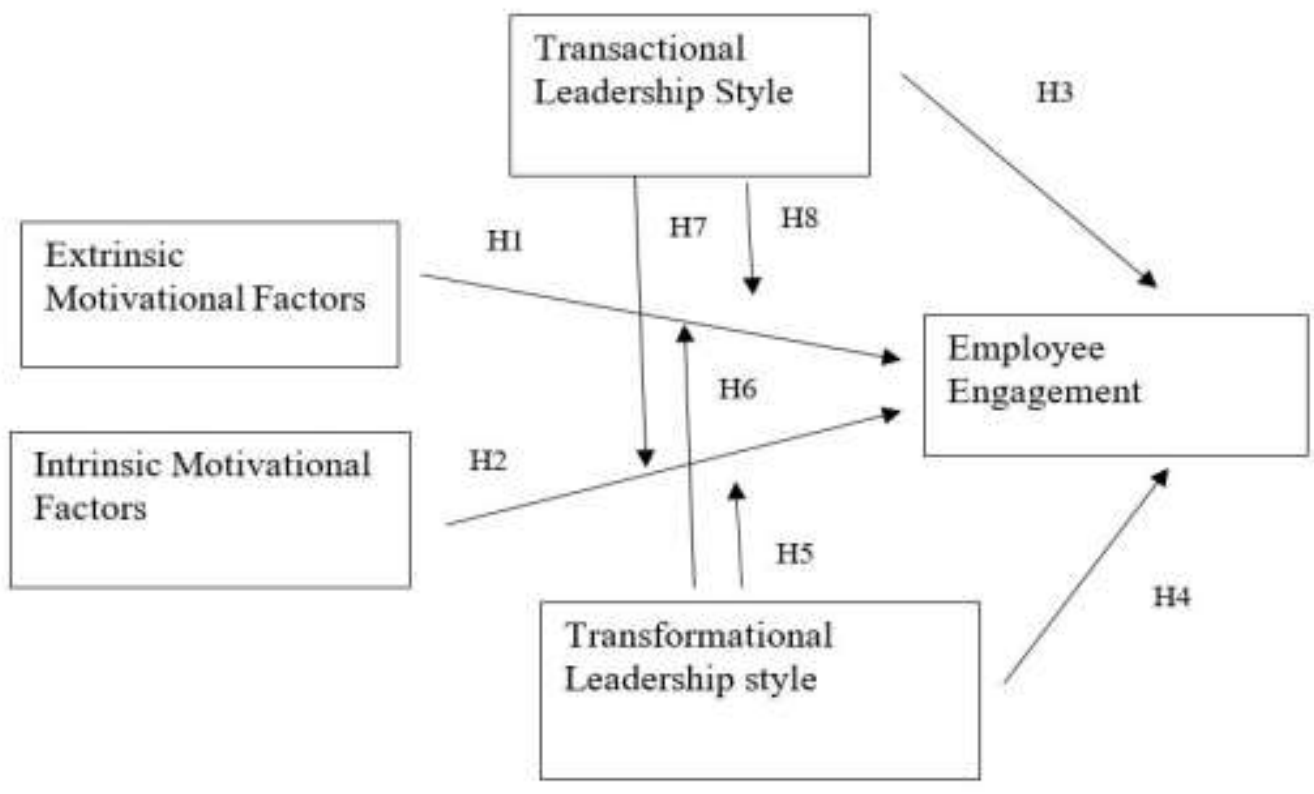

Figure 1. Conceptual Framework

H1: There is significant effect of extrinsic motivational factors on employee engagement at the readymade garments industry in Bangladesh.

H2: There is significant effect of intrinsic motivational factors on employee engagement at the readymade garments industry in Bangladesh.

Past literature such as [35] and [36] state that motivation can increase employee engagement. [37] has suggested that there is a relationship between improvement of intrinsic motivational factors (IMF) and extrinsic motivational factors (EMF) and enhancement of employee engagement in organization. [13] and [38] also express that IMF and EMF have positive effect on employee engagement. [1] suggest that motivator increase the employee engagement as well as caution that appropriate amounts of attention must be paid to extrinsic factors to avoid dissatisfaction. Grounded by the theory, the researcher proposes that leaders must first attend to the lower order of hygiene needs before using intrinsic motivation factors to develop satisfaction and job achievement. Promotion and growth, recognition, creativity, independence, moral values, responsibility and ability to utilize are intrinsic motivational factors which are crucial and could only be achieved if the basic hygiene needs are fulfilled. On the other hand, job security, salary, relationship with peers, relationship with supervisor, working environment, company policy and procedure, authority, variety are extrinsic motivational factors which encourage employees to be engaged in their work seriously. Thus, the above hypotheses are formulated based on these facts. 
[38, 30] discover that motivation and its components have positive and significant association with leadership style. Transformational leaders encourage employee intrinsically such as by trusting the workers, admiring their loyalty, and respect while, transaction leaders use reward and punishment methods to motivate the employees According to the full range leadership theory, transformational leader motivates the employees intrinsically using the elements which drive the motivation factors suggested by Herzberg and transactional leader motivates the employee extrinsically and the element is driven from hygienic factors of Herzberg.

According to the full range leadership theories, manager wants to reduce dissatisfaction among the employees by providing extrinsic motivation to prevent burn out and to increase employee's engagement by providing intrinsic motivation. This is done by trusting the workers, and express admiration for their loyalty, and respect. The next hypothesis is drawn based on this fact. The following hypothesis is based on this perspective.

H3: There is significant effect of transactional leadership style on employee engagement at the readymade garments industry in Bangladesh.

H4: There is significant effect of transformational leadership style on employee engagement at the readymade garments industry in Bangladesh.

H5: Transformational leadership style moderates the relationship between intrinsic motivational factors and employee engagement at the readymade garments industry in Bangladesh.

H6: Transformational leadership style moderates the relationship between extrinsic motivational factors and employee engagement at the readymade garments industry in Bangladesh.

H7: Transactional leadership style moderates the relationship between intrinsic motivational factors and employee engagement at the readymade garments industry in Bangladesh.

H8: Transactional leadership style moderates the relationship between extrinsic motivational factors and employee engagement at the readymade garments industry in Bangladesh.

\section{METHODOLOGY}

Sample, Data Collection and Measurement

This study was based on empirical data and used a structured questionnaire. The populations of the study were the permanent employees of the RMG industry in Bangladesh. The sampling was based on non-probability and convenience sampling, as it is a better approach for this study. The study collected a total of 387 responses from 25 RMG factories in Dhaka.

The Utrecht Work Engagement (UWES) scale of employee engagement, developed by [39] and tested by [40] consists of a 9 item questionnaire to measure 3 dimensions (vigor, dedication, absorption) of employee engagement.

To measure motivational factors, the scale developed by [41] and used by [42] named the 'Minnesota Satisfaction Questionnaire' was adopted for this study. The motivational factors consist of achievement, recognition, relationship with supervisor, company policy and procedure. These factors are also categorized into intrinsic and extrinsic motivational factors.

The transformational and transactional leadership constructs were measured by a multifactor leadership questionnaire (MLQ) (5X) with the scale developed by [29]. Transformational leadership was measured by individualised consideration and transactional leadership was measured by contingent reward. All questions used ratings based on 5-point Likert scales, ranging from 1 = strongly disagree to 5 = strongly agree. Data were analysed using SPSS for demographic and descriptive elements, and Smart PLS was used to measure the covariance-based structural equation modeling (SEM) technique. 


\section{RESULTS AND FINDINGS}

\subsection{Demographic Part}

Table -1 Demographic Profile of the Respondents

\begin{tabular}{|c|c|c|c|}
\hline Profile & Category & $\mathbf{n}$ & $\%$ \\
\hline \multirow{5}{*}{ Age } & Below 18 & 46 & 11.9 \\
\hline & $18-25$ & 179 & 46.3 \\
\hline & $26-33$ & 114 & 29.5 \\
\hline & $34-41$ & 40 & 10.3 \\
\hline & More than 41 & 8 & 2.1 \\
\hline \multirow{3}{*}{ Gender } & Male & 260 & 67.2 \\
\hline & Female & 126 & 32.6 \\
\hline & Common gender & 1 & 0.3 \\
\hline \multirow{4}{*}{ Marital status } & Single & 160 & 41.3 \\
\hline & Married & 226 & 58.4 \\
\hline & Others & 1 & 0.3 \\
\hline & Primary & 195 & 50.4 \\
\hline \multirow{3}{*}{ Education level } & Secondary & 157 & 40.6 \\
\hline & Higher secondary & 29 & 7.5 \\
\hline & Bachelor & 6 & 1.6 \\
\hline \multirow{7}{*}{ Monthly income } & Below TK. 5300 & 24 & 6.2 \\
\hline & TK. 5300 to TK. 7000 & 49 & 12.7 \\
\hline & TK. 7001 to TK. 9000 & 124 & 32 \\
\hline & TK. 9001 to TK. 11000 & 69 & 17.8 \\
\hline & TK. 11001 to TK. 13000 & 72 & 18.6 \\
\hline & TK. 13001 to TK. 15000 & 37 & 9.6 \\
\hline & Above TK. 15000 & 12 & 3.1 \\
\hline \multirow{5}{*}{ Work experience } & Less than 1 year & 65 & 16.8 \\
\hline & 1 to 3 years & 173 & 44.7 \\
\hline & 4 to 6 years & 113 & 29.2 \\
\hline & 7 to 9 years & 19 & 4.9 \\
\hline & More than 9 years & 17 & 4.4 \\
\hline \multirow{6}{*}{ Working hours per week } & Below than 48 & 5 & 1.3 \\
\hline & Between 48 to 54 & 93 & 24 \\
\hline & Between 55 to 60 & 114 & 29.5 \\
\hline & Between 61 to 66 & 68 & 17.6 \\
\hline & Between 67 to 72 & 67 & 17.3 \\
\hline & More than 72 & 40 & 10.3 \\
\hline
\end{tabular}




\subsection{Descriptive Findings}

Table -2 Mean and standard deviation of motivational factors, leadership styles and employee engagement

\begin{tabular}{lccc}
\hline & Variables & Mean & Std. Deviation \\
\hline Intrinsic motivation & 3.25 & 0.58 \\
Extrinsic motivation & 3.35 & 0.61 \\
transformational leadership & 3.6 & 0.66 \\
transactional leadership & 3.28 & 0.64 \\
employee engagement & 3.71 & 0.5 \\
\hline
\end{tabular}

According to Herzberg's two-factor theory, motivators should increase employee engagement. In terms of the average mean and standard deviation (Table 2), the results of this study indicate that employees were not able to value motivational factors and as a result, they described themselves as unsatisfied in their work. The overall means for the intrinsic and extrinsic motivational factors were $(3.25 \pm 0.58),(3.35 \pm 0.61)$ consecutively, suggesting neutral responses for both types of motivational factor. Further, based on leadership effects, the results showed that the respondents also gave neutral responses for the

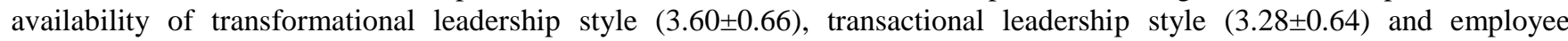
engagement $(3.71 \pm 0.50)$.

\subsection{Assessment of Measurement Model}

According to the standard procedure, the measurement model should be assessed before the structural model. The measurement model analysis includes measuring construct reliability, convergent validity, and discriminant validity. Hair et al., (2014) suggested the use of composite reliability to assess the internal consistency of the study and the threshold value should achieve the value of 0.7. Based on Table 3, the composite reliability values of 0.768 (Employee engagement), 0.870 (Extrinsic motivation), 0.861 (Intrinsic motivation), 0.837 (Transactional leadership) and 0.884 (Transformational leadership) demonstrate that these constructs have high levels of internal consistency in this study. 


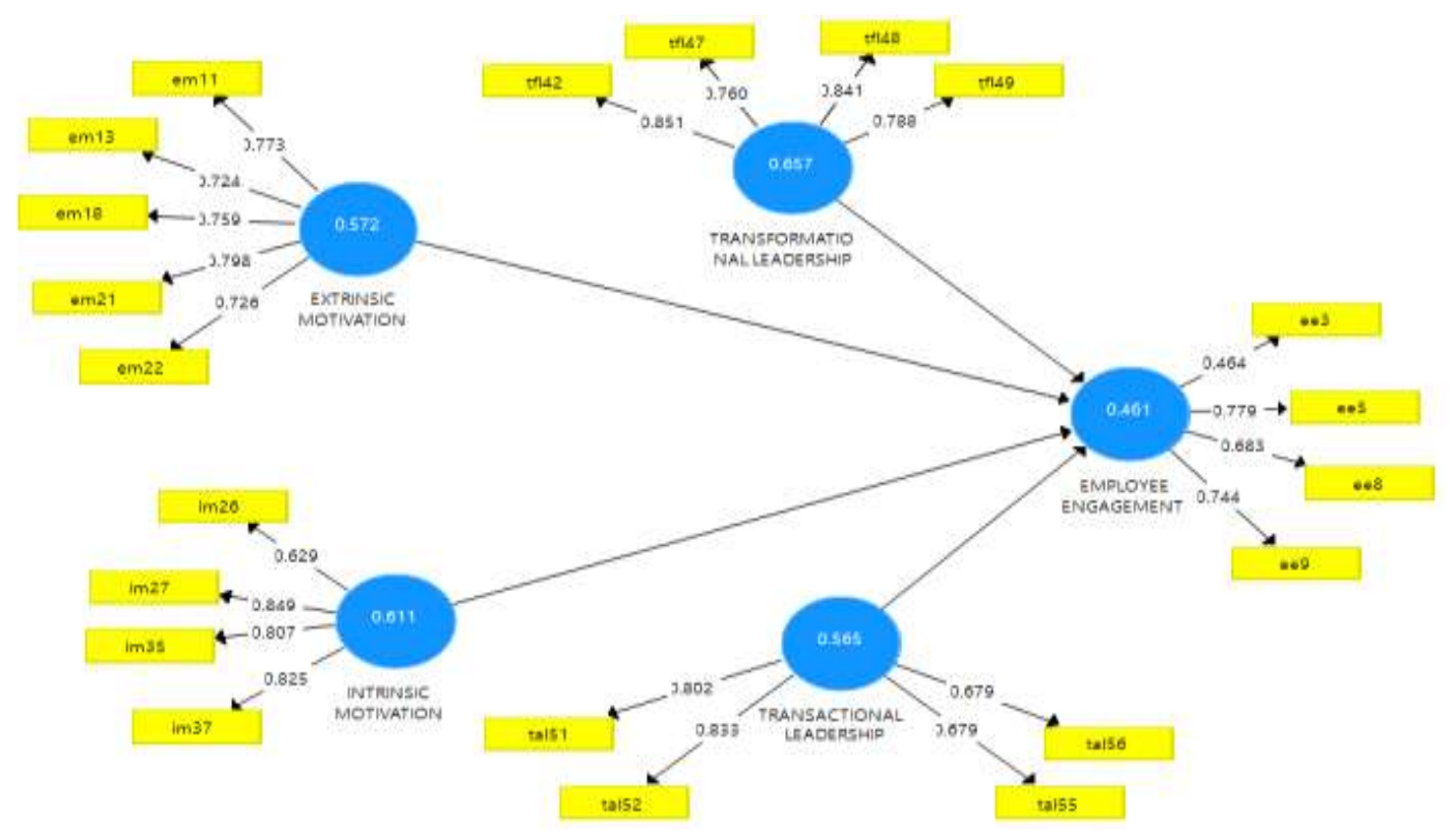

Figure 2. Measurement Model

Table -3 Convergent validity, CR and AVE

\begin{tabular}{|c|c|c|c|c|}
\hline Items & Outer loadings & $\mathbf{C A}$ & CR & AVE \\
\hline EMPLOYEE ENGAGEMENT & & 0.602 & 0.768 & 0.461 \\
\hline Dedication & 0.464 & & & \\
\hline Vigor & 0.779 & & & \\
\hline Absorption & 0.683 & & & \\
\hline Absorption & 0.744 & & & \\
\hline EXTRINSIC MOTIVATION & & 0.813 & 0.870 & 0.572 \\
\hline Company policies and procedures & 0.773 & & & \\
\hline Authority & 0.724 & & & \\
\hline Relationship with supervisor & 0.759 & & & \\
\hline Advancement & 0.798 & & & \\
\hline Salary & 0.726 & & & \\
\hline INTRINSIC MOTIVATION & & 0.784 & 0.861 & 0.611 \\
\hline Ability utilization & 0.629 & & & \\
\hline Achievement & 0.849 & & & \\
\hline Responsibility & 0.807 & & & \\
\hline Recognition & 0.825 & & & \\
\hline TRANSACTIONAL LEADERSHIP & & 0.744 & 0.837 & 0.565 \\
\hline Contingent reward & 0.802 & & & \\
\hline Contingent reward & 0.833 & & & \\
\hline Management by exception passive & 0.679 & & & \\
\hline Management by exception passive & 0.679 & & & \\
\hline $\begin{array}{l}\text { TRANSFORMATIONAL } \\
\text { LEADERSHIP }\end{array}$ & & 0.826 & 0.884 & 0.657 \\
\hline
\end{tabular}




\begin{tabular}{ll} 
Idealized influence & 0.851 \\
Intellectual stimulation & 0.760 \\
Intellectual stimulation & 0.841 \\
Individual consideration & 0.788 \\
\hline
\end{tabular}

Convergent validity (AVE) is used to check the level of convergence of a given individual construct in comparison to the measure of other constructs [43]. This indicates the degree upon which a latent construct elaborates the variances that exist within its indicators [44]. Table 3 illustrates that all of the AVE values for this study are around 0.5.

Discriminant validity, as suggested by [45], is commonly used to assess the degree of shared variance between the latent variables of the model. The results in Table 4 illustrate satisfactory or sufficient discriminant validity as recommended, where the square roots of AVE (diagonal) are higher than the correlations (off-diagonal) for all the reflective constructs.

Table -4 Discriminant validity and Structural modeling in PLS-SEM

\begin{tabular}{|c|c|c|c|c|c|c|c|c|c|c|c|}
\hline & \multicolumn{5}{|c|}{ Fornell-Larcker } & \multirow{2}{*}{$\begin{array}{c}\begin{array}{c}\text { Inner } \\
\text { VIF }\end{array} \\
\text { Y1 }\end{array}$} & \multirow{2}{*}{$\begin{array}{c}\mathrm{f} \\
\text { Square } \\
\mathrm{Y} 1\end{array}$} & \multirow[t]{2}{*}{$\begin{array}{c}\mathrm{R} \\
\text { Square } \\
\end{array}$} & \multicolumn{3}{|c|}{ Construct Cross validated Redundancy } \\
\hline & Y1 & $\mathrm{Y} 2$ & $\mathrm{Y} 3$ & Y4 & Y5 & & & & SSO & SSE & $\begin{array}{c}\mathrm{Q}^{2}(=1- \\
\mathrm{SSE} / \mathrm{SSO})\end{array}$ \\
\hline $\begin{array}{l}\text { EMPLOYEE } \\
\text { ENGAGEMENT (Y1) }\end{array}$ & 0.679 & & & & & & & 0.536 & 1548.000 & 1166.971 & 0.246 \\
\hline $\begin{array}{l}\text { EXTRINSIC } \\
\text { MOTIVATION (Y2) }\end{array}$ & 0.672 & 0.757 & & & & 3.274 & 0.035 & & & & \\
\hline $\begin{array}{l}\text { INTRINSIC MOTIVATION } \\
\text { (Y3) }\end{array}$ & 0.667 & 0.749 & 0.782 & & & 2.948 & 0.042 & & & & \\
\hline $\begin{array}{l}\text { TRANSACTIONAL } \\
\text { LEADERSHIP (Y4) }\end{array}$ & 0.603 & 0.678 & 0.665 & 0.752 & & 2.068 & 0.038 & & & & \\
\hline $\begin{array}{l}\text { TRANSFORMATIONAL } \\
\text { LEADERSHIP (Y5) }\end{array}$ & 0.630 & 0.753 & 0.728 & 0.549 & 0.811 & 2.693 & 0.026 & & & & \\
\hline
\end{tabular}

\subsection{Structural modeling in PLS-SEM}

According to the results shown in Table 4, it can be observed that the inner VIF values for each construct are within the range of 3.27-2.07, thus there is absence of multicollinearity issues in this study [46]. The coefficient of determination score is used to assist a given model's ability to predict. In other words, the R square measures a given model's predictive ability. [44] proposed a range of $0.75,0.5$, and 0.25 as typical substantial, moderate, and weak levels of predictive accuracy, respectively. Table 4 suggests that the relationships between the constructs under investigation are moderate [44]. It found to be 0.536 indicating that motivational factors and leadership styles can account for $53.6 \%$ of the variance in the employee engagement.

The f square value of $0.35,0.15$ and 0.02 represents large, medium, and small effect sizes, respectively. Based on the result in Table 4, transformational leadership (0.026), transactional leadership (0.038), intrinsic motivation (0.042) and extrinsic motivation (0.035) are shown to have a small effect size (f square) on employee engagement [47]. 
An additional criterion for evaluating the quality of the model is the blindfolding procedure to assess a model's capability to predict [48]. [48] recommended using cross-validated redundancy where the use of PLS-SEM is required to estimate both the structural model and the measurement model for data prediction. Cross-validated redundancy is perfectly suitable for the PLSSEM approach. [49] suggested that if the Q square value is greater than zero, then the model has predictive relevance. From Table 4, the values of Q square for leadership styles and employee engagement show that they are greater than 0 , hence predictive relevance is attained.

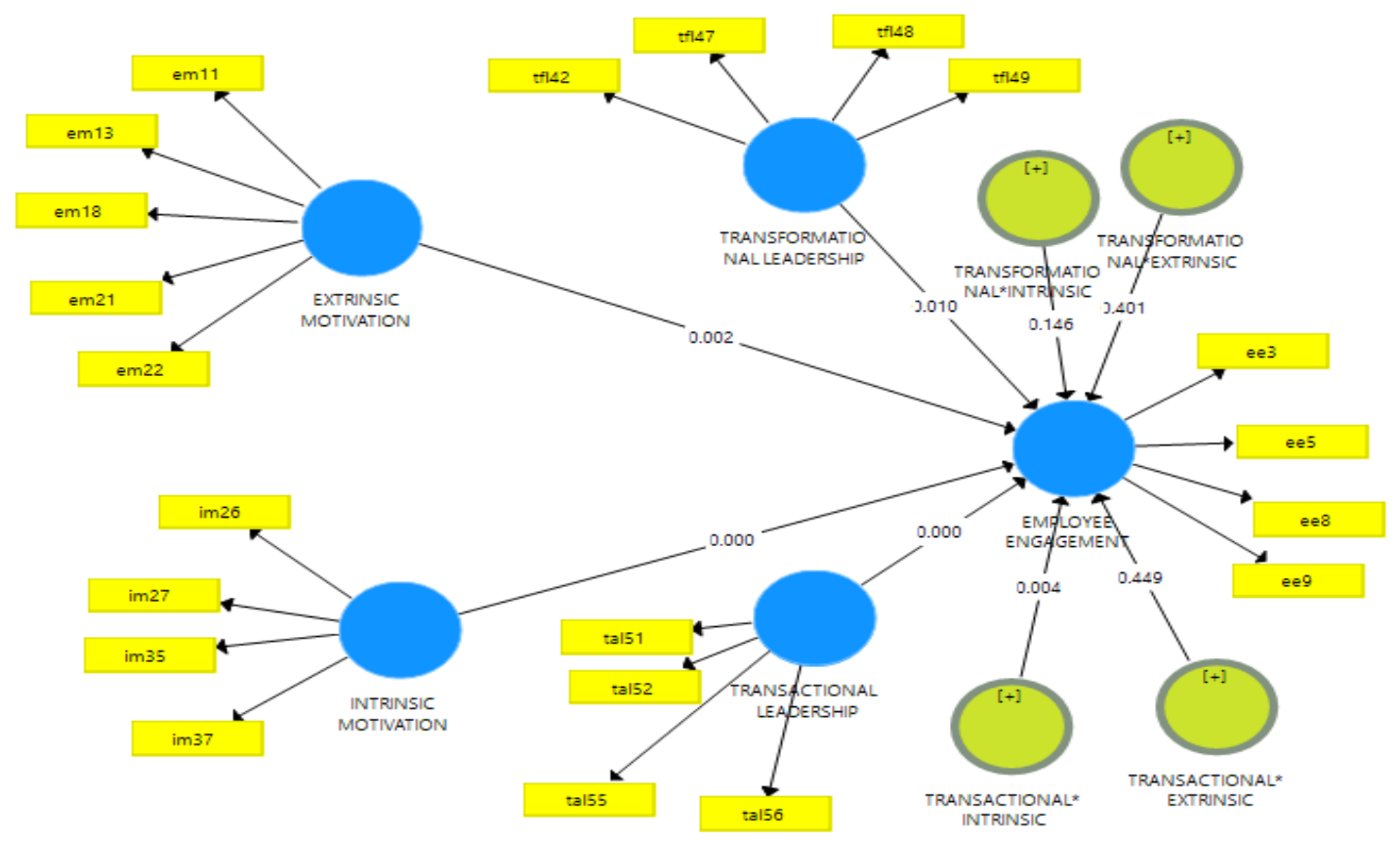

Figure 3. Structural Model

VII. HYPOTHESIS TESTING

Path coefficient

Table 5 illustrates the significant effect of extrinsic motivational factors on employee engagement $(b=0.241, t=3.121, p<0.05)$; the effect of intrinsic motivational factors on employee engagement $(b=0.238, t=3.849, p<0.05)$; transactional leadership style on employee engagement $(b=0.190, t=3.596, p<0.05)$. Transformational leadership style on employee engagement $(b=0.175$, $\mathrm{t}=2.577, \mathrm{p}<0.05)$. Thus, hypothesis $1,2,3$ and 4 have been accepted.

Table -5 Path Coefficients

\begin{tabular}{|c|c|c|c|c|c|}
\hline & $\begin{array}{c}\text { Original } \\
\text { Sample }(O)\end{array}$ & $\begin{array}{c}\text { Sample } \\
\text { Mean (M) }\end{array}$ & $\begin{array}{c}\text { Standard } \\
\text { Deviation } \\
\text { (STDEV) }\end{array}$ & $\begin{array}{l}\text { T Statistics } \\
\text { (|O/STDEV } \mid)\end{array}$ & $\begin{array}{c}\mathrm{P} \\
\text { Values }\end{array}$ \\
\hline EXTRINSIC MOTIVATION -> EMPLOYEE ENGAGEMENT & 0.241 & 0.246 & 0.077 & 3.121 & 0.002 \\
\hline INTRINSIC MOTIVATION -> EMPLOYEE ENGAGEMENT & 0.238 & 0.234 & 0.062 & 3.849 & 0.000 \\
\hline TRANSACTIONAL LEADERSHIP -> EMPLOYEE ENGAGEMENT & 0.190 & 0.191 & 0.053 & 3.596 & 0.000 \\
\hline
\end{tabular}




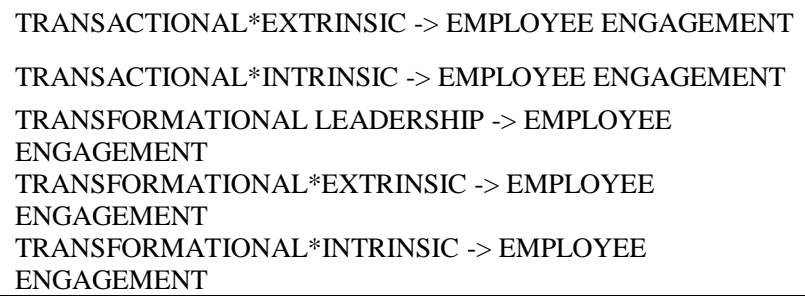

\begin{tabular}{lllll}
0.053 & 0.057 & 0.070 & 0.757 & 0.449 \\
-0.199 & -0.200 & 0.069 & 2.889 & 0.004 \\
0.175 & 0.174 & 0.068 & 2.577 & 0.010 \\
0.059 & 0.056 & 0.070 & 0.841 & 0.401 \\
0.097 & 0.098 & 0.067 & 1.454 & 0.146 \\
\hline
\end{tabular}

The transactional leadership style moderates the relationship between intrinsic motivational factors and employee engagement $(\mathrm{b}=-0.199, \mathrm{t}=2.889, \mathrm{p}<0.05)$, therefore hypothesis $\mathrm{H} 7$ has been accepted. But there is moderating effect of transactional leadership style between the relationship of extrinsic motivational factors and employee engagement $(b=0.053, t=0.757$, $\mathrm{p}>0.05$ ). Hence, hypothesis $\mathrm{H} 8$ has been rejected. On the other hand, there is no moderating effect of transformational leadership style between the relationship of extrinsic motivational factors and employee engagement $(b=0.059, t=0.841$, $\mathrm{p}>0.05)$ as well as between the relationship of intrinsic motivational factors and employee engagement $(b=0.097, t=1.454$, $\mathrm{p}>0.05)$. Thus, hypothesis H6 and $\mathrm{H} 5$ have been rejected.

\section{DISCUSSION}

This study examined the relationship among extrinsic motivational factors, intrinsic motivational factors, transactional leadership style, transformational leadership style and employee engagement at the RMG industry in Bangladesh. This paper has clearly demonstrated that there are a significant relationship between extrinsic motivational factors and employee engagement, intrinsic motivational factors and employee engagement, transactional leadership style and employee engagement, transformational leadership style and employee engagement in this sector, meaning that these constructs should be the focus of attention in efforts to increase and promote engagement among the employees at the RMG factories in Bangladesh.

The first objective of this paper was to test the relationship between motivational factors and employee engagement as well as leadership styles and employee engagement. The hypothesis $\mathrm{H} 1$ and $\mathrm{H} 2$ confirm that extrinsic motivational factors (company policy and procedure, authority, relationship with supervisor, advancement, salary) and intrinsic motivational factors (ability utilization, achievement, responsibility, recognition) have a significant effect on employee engagement (dedication, vigor, absorption). This result is similar to the findings of [13] and [50]. According to past studies, Leadership can increase group performance and job satisfaction through motivation [51]. This study anticipated that there would be a significant effect of leadership styles, specifically transformational (idealized influence, intellectual stimulation, individual consideration) and transactional style (contingent reward, management by exception passive) on employee engagement (dedication, vigor, absorption). The hypothesis $\mathrm{H} 3$ and $\mathrm{H} 4$ confirm that employees engaged at the RMG industry do need support from their supervisor and managers, either by using a transformational or a transactional approach. This result is similar to [32] and [52], who concluded that transactional leadership and transformational leadership are strong predictors of employee engagement. The R squared result also showing that motivational factors and leadership styles have a 53.6\% effect on employee engagement, which is moderately significant.

The second objective of this paper was to test the moderating effect of leadership styles on the relationship between motivational factors and employee engagement in the RMG industry of Bangladesh. This is based on the common understanding that employees need not only motivation but also support and commitment from supervisors and managers if there is to be an increase in their engagement in the workplace $[53,54,55]$.

The hypothesis $\mathrm{H} 7$ testing of this study confirmed that the transactional leadership style (contingent reward, management by exception passive) moderates the relationship between intrinsic motivational factors (ability utilization, achievement, responsibility, recognition) and employee engagement (dedication, vigor, absorption). But transactional leadership style (contingent reward, management by exception passive) does not moderate the relationship between extrinsic motivational factors (company policy and procedure, authority, relationship with supervisor, advancement, salary) and employee engagement (dedication, vigor, absorption) according to hypothesis $\mathrm{H} 8$. 
In accordance with hypothesis H5 and 6, Transformational leadership style (idealized influence, intellectual stimulation, individual consideration) does not moderate the relationship between extrinsic motivational factors (company policy and procedure, authority, relationship with supervisor, advancement, salary) and employee engagement as well as the relationship between intrinsic motivational factors (ability utilization, achievement, responsibility, recognition) and employee engagement at readymade garments industry in Bangladesh.

The results suggest that motivational factors and leadership styles, have influence on determining employee engagement, which suggests that if they are not satisfied in their work then it will be difficult for employees in the RMG to be motivated to 'go the extra mile' as suggested in the concept of employee engagement. This also suggests that in this case, intrinsic motivational factors should have more of a priority than extrinsic motivational factors according to Table 5. In other words, transactional leadership style is able to boost employee engagement more than transformational leadership style.

We need to provide ability utilization, achievement, responsibility, recognition to the employee of readymade garments industry in Bangladesh for better engagement of the employee while contingent reward (it is used to reward the employee who meet their identified goals), management by exception passive (the leader only interferes when goals have not been met or, leaders interfere when mistakes occurred) play moderating role.

\section{CONCLUSIONS AND RECOMMENDATIONS}

This study has important implications for both theoretical and practical reasons. In particular, the point should be made that most of the previous related literature on employee engagement studied this issue in a Western industrial context. This paper is one of the few studies which focuses on the Ready Made Garment (RMG) industry of Bangladesh, which is one of the most important industries in that country. This study is also significant because, the respondents were from an operational level; mainly low-income employees who have a high reliance on employers who can overcome areas of dissatisfaction, meet their needs and motivate them.

In sum, this study has identified that in the case of the RMG sector of Bangladesh, managers are advised to focus on building motivational factors, particularly intrinsic values, before they can focus on how leadership might influence employee engagement. By doing so, managers will strengthen their relationship with their employees, leading to a good congruence. This is because, even though the leadership style of managers might ensure congruence between manager and employee, managers must be able to clearly express their expectations and concerns to their employees. This can be accomplished, for example, by putting an emphasis on training needs and career development opportunities which would demonstrate their commitment and support for their employees.

\section{FUTURE RESEARCH}

This study was limited in several ways, prompting the need for future investigation. The sample was limited to the employees who are involved in production and their potential differences in demographic and psychological aspects were not taken into consideration. In addition, this study only examined the effect of motivational factors (intrinsic or extrinsic) and leadership styles (transformational and transactional) on employee engagement and moderating effect of leadership styles between the variables. Demographic (age, sex) expect should also be investigated in order to provide more insights into employee engagement. Researchers should also consider multilevel and longitudinal studies for better and more accurate outcomes for this study. 


\section{REFERENCES}

[1] Herzberg, F. M., \& Mausner, B. (1959). B. \& Snyderman, B.(1959). The motivation to work, 2, 49-58.

http://www.dhakatribune.com/business/2015/may/04/bangladeshs-50bn-rmg-export-target-2021. [Accessed 7 June, 2019].

[2] Kahn, W. A. (1990). "Psychological conditions of personal engagement and disengagement at work", The Academy of Management Journal, Vol. 33 No. 4, pp. 692-724.

[3] Marelli, A. F. (2011). Employee engagement and performance management in the federal sector. Performance Improvement, 50(5), 5-13.

[4] Bailey, C., Madden, A., Alfes, K., \& Fletcher, L. (2017). The meaning, antecedents and outcomes of employee engagement: A narrative synthesis. International Journal of Management Reviews, 19(1), 31-53.

[5] BGMEA. (2018). Trade Information. Retrieved from http://www.bgmea.com.bd/home/pages/tradeinformation

[6] Rubel, M. R. B., Kee, D. M. H., Quah, C. H., \& Rimi, N. N. (2017). Ethical Climate and Employee Turnover Intention in the Ready-Made Garment Industry of Bangladesh. Global Business and Organizational Excellence, 36(2), 61-73.

[7] Jensen, J. D. (2018). Employee Motivation : A Leadership Imperative, 9(2), 93-98.

[8] Jones, R. J., \& Sloane, P. J. (2007). Low pay, higher pay and job satisfaction in Wales. Spatial Economic Analysis, 2(2), 197-214.

[9] Wang, H. J., Lu, C. Q., \& Lu, L. (2014). Do people with traditional values suffer more from job insecurity? The moderating effects of traditionality. European Journal of Work and Organizational Psychology, 23(1), 107-117.

[10] Iqbal, N. (2015). Impact of Rewards and Leadership on the Employee Engagement in Conventional Banking Sector of Southern Punjab. Arabian Journal of Business and Management Review, 57(4), 30-34.

[11] Schaefer, Z. (2015). Transformational vs. Transactional Leaders : How Different Leadership Behaviors and Communication Styles Affect Levels of Employee Motivation in the Financial Industry.

[12] Schmitt, A., Den Hartog, D. N., \& Belschak, F. D. (2016). Transformational leadership and proactive work behaviour: A moderated mediation model including work engagement and job strain. Journal of Occupational and Organizational.

[13] Bergstrom \& Martinez (2016). The Influence of Intrinsic and Extrinsic Motivation on Employee Engagement. Umea School of Business and Economics.

[14] Othman, A. K., Hamzah, M. I., Abas, M. K., \& Zakuan, N. M. (2017). The influence of leadership styles on employee engagement: The moderating effect of communication styles. International Journal of Advanced and applied scienceS, 4(3), 107-116.

[15] Mung, L. V., May-Chiun, L., Kwang Sing, N., \& Ayob, N. (2011). The Influence of Leadership Styles on Employees 'Job Satisfaction in Public Sector Organizations in Malaysia. International Journal of Business, Management and Social Sciences, 2(1), 24-32.

[16] Mansor, Z. D., Jaharudin, N. S., \& Nata, N. M. (2018). Employee Engagement in Public Organizations in Malaysia. Proceeding of the 5th International Conference on Management and Muamalah, 2018(ICoMM), 258-272.

[17] Schaufeli, W. B., Salanova, M., González-Romá, V., \& Bakker, A. B. (2002). The measurement of engagement and burnout: A two sample confirmatory factor analytic approach. Journal of Happiness studies, 3(1), 71-92.

[18] Engelbrecht, A. S., Heine, G., \& Mahembe, B. (2017). Integrity, ethical leadership, trust and work engagement. Leadership \& Organization Development Journal, 38(3), 368-379.

[19] Ariani, D.W. (2013). The Relationship between Employee Engagement, Organizational Citizenship Behavior, and Counterproductive Work Behavior. International Journal of Business Administration, 4, 46-56.

[20] Schaufeli, W. B., \& Bakker, A. B. (2003). Utrecht Work Engagement Scale (UWES): Test manual. Unpublished manuscript. Department of Psychology, Utrecht University, The Netherlands

[21] Storm, K., \& Rothmann, I. (2003). A psychometric analysis of the Utrecht Work Engagement Scale in the South African police service. South African Journal of Industrial Psychology, 29, 62-70.

[22] Christian, M.S., Garza, A.S. and Slaughter, J. E. (2011). Work engagement: a quantitative review and test of its relations with task and contextual performance. Personnel Psychology, 64, 89-136.

[23] Kathirvel, N. (2010). A Study on the Morale of Employees with Reference to Textile Industries in Coimbatore. The IUP Journal of Management Research, 4(3), 61-81.

[24] Parashar, B. K. (2016). Significance of Theory Z in Indian Scenario. International Journal of Management and Social Sciences Research (IJMSSR), $5(2), 8-16$. 
[25] Lin, H. F. (2007). Effects of extrinsic and intrinsic motivation on employee knowledge sharing intentions. Journal of Information Science.

[26] Davies, S. J. (2007). Security supervision and management: The theory and practice of asset protection. Amsterdam, Netherlands: ButterworthHeinemann/Elsevier.

[27] Nelson, D. L., \& Quick, J. C. (2008). Understanding organizational behavior (3rd ed.). Mason, OH: Thomson South-Western. Nguni.

[28] Chaudhry, A. Q., Javed, H., \& Sabir, M. (2012). The Impact Of Transformations And Transactional Leadership Styles On The Motivation Of Employees In Pakistan. Pakistan Economic and Social Review, 50(2), 223-231.

[29] Bass, B.M., Avolio, B. J. (1991). The full range of leadership development: Basic and advanced manuals. Binghampton, NY: Bass, Avolio and Associates.

[30] Bass, B. M. (1990). Bass \& Stogdill’s Handbook of Leadership. Bass Stogdills Handbook of Leadership, 3rd, 2415.

[31] Mester, C., Roodt, G., \& Kellerman, R. (2003). Leadership Style and Its Relation To Employee Attitudes and Behaviour. SA Journal of Industrial Psychology, 29(2), 72-82.

[32] Shuck, B., \& Herd, A. M. (2012). Employee Engagement and Leadership: Exploring the Convergence of Two Frameworks and Implications for Leadership Development in HRD. Human Resource Development Review, 11(2), 156-181.

[33] Lussier, R. N. \& Achua, C. F. (2010), Leadership: Theory Application and Skill Development, 4th Edition USA: Cengage Learning

[34] Yisa, Alkali, O. (2013). Review ratio analysis: paradigm for identifying causes of corporate failure. International Journal of Management Reserach and Review, 3(11), 3819-3825.

[35] Kahn, W. A. (1990). Psychological conditions of personal engagement and disengagement at work. Academy of management journal, 33(4), 692-724.

[36] Marelli, A. F. (2011). Employee engagement and performance management in the federal sector. Performance Improvement, 50(5), 5-13.

[37] Silvera, I. (2013). Motivation schemes can build long-term engagement. Employee benefits, 1-7.

[38] Kahn, W. A. (2010). The essence of engagement: Lessons from the field. Handbook of employee engagement: Perspectives, issues, research and practice, 20-30.

[39] Schaufeli, W. B., Bakker, A. B., \& Salanova, M. (2006). The measurement of work engagement with a short questionnaire: A cross-national study. Educational and Psychological Measurement, 66(4), 701-716.

[40] Vanam, S. (2009). Job engagement: examining the relationalship with situational and personal factors. San José State University.

[41] Weiss, D., Dawis, R., England, G. \& Lofguist, L. (1967). Manual for the Minnesota Satisfaction Questionnaire, Minnesota: Industrial Relations Center: University of Minnesota.

[42] Ghanbahadur, R. R. (2014). To test the effectiveness of Hygiene-Motivation factors on Irish Accountants and American Engineers in predicting Intrinsic-Extrinsic job satisfaction (Doctoral dissertation, Dublin, National College of Ireland).

[43] Urbach, N., \& Ahlemann, F. (2010). Structural equation modeling in information systems research using partial least squares. Journal of Information Technology Theory and Application, 11(2), 5-40.

[44] Hair Jr, J. F., Sarstedt, M., Ringle, C. M., \& Gudergan, S. P. (2017). Advanced issues in partial least squares structural equation modeling. Sage Publications.

[45] Fornell, C., \& Larcker, D. F. (1981). Structural equation models with unobservable variables and measurement error: Algebra and statistics.

[46] Diamantopoulos, A., \& Siguaw, J. A. (2006). Formative versus reflective indicators in organizational measure development: A comparison and empirical illustration. British journal of management, 17(4), 263-282.

[47] Hair Jr, J. F., Hult, G. T. M., Ringle, C., \& Sarstedt, M. (2016). A primer on partial least squares structural equation modeling (PLS-SEM). Sage publications.

[48] Hair, J. F., Ringle, C. M., \& Sarstedt, M. (2011). PLS-SEM: Indeed a silver bullet. Journal of Marketing theory and Practice, 19(2), 139-152.

[49] Fornell, C. and Cha, J. (1994). Partial Least Squares. Advanced Methods of Marketing Research, 407, 52-78.

[50] Putra, E. D., Cho, S., \& Liu, J. (2015). Extrinsic and intrinsic motivation on work engagement in the hospitality industry: Test of motivation crowding theory. Tourism and Hospitality Research.

[51] Nader, M. A. (2019). Shared-Leadership: A Path toward Happiness or Discontent (Doctoral dissertation, St. Thomas University). 
[52] Devi, V. R., \& Narayanamma, P. L. (2016). Impact of Leadership Style on Employee Engagement. Pacific Business Review International, 1(1), 91-98. Retrieved from http://www.ccsenet.org/journal/index.php/ijbm/article/view/24702

[53] Akter, S. (2016). Leadership and Organisational factors for creating Sustainable Readymade garment (RMG) sector in Bangladesh. Retrieved from https://dspace.mah.se/handle/2043/21497

[54] Khatun, R. (2017). Job Satisfaction of RMG Sectors in Bangladesh : A Study on Female Workers of AKH Group, International Journal of Humanities \& Social Science Studies (IJHSSS), 3(6), 97-106.

[55] Akterujjaman, S. M., \& Ahmad, M. H. (2016). Workers' Satisfaction toward RMG Industry in Bangladesh: A Study on Dhaka and Gazipur City. International Journal of Research in Management \& Business Studies, 3(2), 22-30. 